\title{
ALUR PROSES KOGNITIF DAN REAKSI NON-VERBAL KETIKA BERBOHONG
}

\author{
Erik Saut H Hutahaean ${ }^{1}$, Tugimin Supriyadi², Anifah ${ }^{3}$, Trias Fachman \\ Putra $^{4}$ \\ Universitas Bhayangkara Jakarta Raya
}

\begin{abstract}
Abstrak
Penelitian ini bertujuan untuk mengetahui cara proses kognitif yang terjadi ketika seseorang memodifikasi informasi dan mengenali reaksi non-verbal yang muncul secara bersamaan ketika individu berbohong. Subjek dari penelitian ini terbagi menjadi dua, yang pertama adalah 25 orang dewasa dengan jenis kelamin pria dan wanita kami libatkan untuk mendapatkan sistematika proses kognitif berbohong, serta 20 orang dewasa yang kemudian dibagi menjadi 2 kelompok untuk melihat reaksi-reaksi yang muncul saat seseorang berbohong, yakni kelompok eksperimen dan kelompok control. Metode analisis yang kami gunakan adalah koefisien reprodisibilitas model skala Guttman, Serta metode eksperimen laboratorium untuk menganalisa reaksi-reaksi yang muncul saat seseorang berbohong. Hasil hitung koefisien reprodisibilitas mendapatkan ada lima tahapan kognitif yang sistematis. Hasil hitung komparasi antara kelompok yang mengatakan sebenarnya, dan yang tidak mengatakan sebenarnya, menunjukan adanya perbedaan yang signifikan dalam kemunculan reaksi alis, mata yang mengarah ke sebelah kiri, reaksi menarik bibir, muncul senyuman, dan terjadi jeda sebelum melontarkan jawaban.
\end{abstract}

Kata kunci: tahapan berbohong, modifikasi informasi, reaksi berbohong

\begin{abstract}
This study intends to explore the cognitive processes that occur when someone modifies information and recognizes non-verbal reactions that arise when individuals lie. The subjects in this study were divided into two, the first was 25 adults with male and female sex we were involved to get the sequence of cognitive processes lying, and the second involved 20 adults who were then divided into 2 groups to see the facial reaction that appeared when someone is lying, the experimental group and the control group. The analytical method we use is the Guttman scale reproducibility coefficient, for the first study. The experimental method of mathematical games in the laboratory we do to pay attention to the reactions that arise when someone lies. The calculation results get five stages that are tested proven to be sequential paths. The results of the comparison between the groups that say the truth, and those that do not say the truth, show a significant difference in the appearance of the reaction of the eyebrows, the eyes to the left, the reaction to the lips, a smile, and a pause before making an answer.
\end{abstract}

Keywords: stages of lying, modification of information, lying reactions

3 anifahsulaiman@gmail.com

Fakultas Psikologi Universitas Bhayangkara Jakarta Raya

Jalan Darmawangsa 1 No 1 Jakarta

Alur Proses Kognitif Dan Reaksi Non-Verbal Ketika Berbohong Erik Saut H Hutahaean, Tugimin Supriyadi, Anifah, Trias Fachman Putra 


\section{Pendahuluan}

Sebuah hasil kajian menyebutkan terjadinya suatu proses psikologis ketika individu berbohong, proses pembohong menyampaikan informasi palsu yang dijelaskan melalui komunikasi yang konsisten antara informasi yang sudah diketahui oranglain dengan informasi yang tersimpan dalam memori (Pak \& Zhou, 2013). Berbohong diartikan sebagai perbuatan sadar menyampaikan informasi yang tidak benar (Buller, Buendel, \& Burgoon, 2006) yang dilakukan di dalam suatu mekanisme kognitif (Suchotzki, Crombez, Smulders, \& Meijer, 2015).

Pendekatan komunikasi interpersonal menyebutkan bahwa banyak orang gagal mendeteksi kebohongan (Granhag, Porter, \& Vrij, 2010), dikarenakan ketidakpahaman untuk mendalami ucapan kalimat yang memang sangat sulit untuk dipahami, atau keterangan yang tidak masuk akal, dikenal sebagai ketidakpahaman tentang manajemen informasi(Verschuere, Kleinberg, \& Theocharidou, 2014). Hal tersebut biasanya berkaitan dengan fitur dari pesan yang disampaikan di dalam sebuah konteks komunikasi yang interaktif, penerima informasi tidak menaruh kecurigaan kepada pengirim informasi, karena pengirimnya memiliki keahlian dalam hal perilaku linguistik (Bond, 2008). Fiturfitur terbukti dapat mempunyai daya prediktif (meskipun kecil) untuk mengisyaratkan terjadinya kebohongan.

Penelitian ini bertujuan untuk menganalisis alur berfikir yang terjadi ketika individu berbohong, serta mengetahui proses terbentuknya modifikasi informasi pada orang-orang yang berbohong. Penelitian ini juga bermaksud menggali reaksi non-verbal yang muncul bersamaan dengan terlaksananya perbuatan berbohong. Hasil dari penelitian ini dapat dimanfaatkan oleh orang-orang yang tujuan pekerjaannya mengungkap suatu kebenaran seperti investigator kasus kriminal, pewawancara kerja, dan konselor. hasil dari reaksi non-verbal dapat dimanfaatkan sebagai petunjuk untuk mengenali terjadinya kebohongan.

Kesadaran dan proses kognitif menjelaskan tentang adanya usaha manusia untuk mengingat kembali informasi yang tersimpan di dalam memori, melakukan review tentang kemungkinan adanya ancaman (Carrión, Keenan, \& Sebanz, 
2010), saat pertimbangan tentang ancaman dianggap berbahaya maka informasi yang sebenarnya diganti dengan informasi palsu (Debey, Houwer, \& Verschuere, 2007). Kesadaran pikiran yang kuat menandakan terjadinya proses kognitif yang tinggi. Ketika keadaan proses kognitif tinggi, pola perilaku antara yang jujur dan yang bohong dapat dibedakan melalui pola perilaku (Burgoon \& Schuetzler, 2014).

Bagaimana proses berfikir berjalan saat kebohongan terjadi dalam proses komunikasi? Apabila proses review kognitif menjadi bagian penting untuk menjelaskan terjadinya kebohongan, lantas bagaimana alur proses review berjalan? Karena kebohongan banyak dijelaskan memiliki indikator melalui cara pengucapannya, muncul pertanyaan tentang bagaimana ciri ucapan yang dapat dianggap berbohong? Apakah disertai dengan perilaku yang berbeda dengan orang yang berkata jujur?

\section{Metode Penelitian}

Ada dua metode yang digunakan dalam penelitian ini, pertama adalah pemberian quesioner untuk mengetahui alur kognitif berbohong serta eksperimen menggunakan permainan matematika sederhana untuk melihat reaksi non-verbal yang muncul saat individu berbohong.

\section{a. Alur kognitif berbohong}

Subjek dalam penelitian ini terdiri dari 25 orang dewasa dengan jenis kelamin pria maupun wanita. Sebanyak 22 orang diantaranya adalah mahasiswa yang berusia antara 18-24 tahun, kuesioner yang diberikan kepada mereka adalah pertanyaan apakah mereka pernah berbohong kepada orangtua mereka. Sedangkan 3 subjek berikutnya adalah orang dewasa yang statusnya menikah, pertanyaan yang diajukan kepada mereka adalah apakah mereka pernah berbohong kepada pasangannya.

\section{Tahapan Penelitian}

Penelitian ini menguji lima tahapan kognitif saat berbohong. Hasilnya terdapat lima dimensi, terdiri dari: (1) adanya informasi yang tersimpan terkait dengan pertanyaan yang diberikan, (2) kognitif bekerja mengakses memori, (3) 
kognitif mereview memori akan adanya ancaman, (4) kognitif memodifikasi memori dengan ingatan yang dibuat-dibuat, dan (5) individu mengucapkan informasi yang bukan sebenarnya.

Dalam mengidentifikasi alur kognitif berbohong peneliti melakukan uji reprodisibilitas dengan menggunakan kuantifikasi model skala Guttman, tujuannnya untuk melihat apakah setiap dimensinya merupakan dimensi yang ortogonal (multi dimensional) atau uni-dimensional (Abdi, 2010). Asumsinya adalah jika subjek berkata bohong maka subjek berhasil melakukan tahapan sebelum-sebelumnya, dengan arti jika subjek berhasil melihat adanya ancaman jika memori yang sebenarnya dikatakan. Hasilnya skor reprodisibilitasnya menunjukkan angka 0,904 dengan 12 error.

\section{b. Reaksi Non-verbal berbohong}

subjek penelitian kami adalah 20 orang mahasiswa fakultas psikologi UBJ yang beusia antara 18-24 tahun berjenis kelamin pria dan wanita. Dengan kriteria dapat melakukan operasi hitung matematika sederhana. Sebanyak 10 subjek dijadikan sebagai kelompok subjek yang diberikan perlakuan untuk memodifikasi jawaban yang sebenarnya dan tidak mengatakan yang sebenarnya. 10 lainnya dijadikan sebagai kelompok subjek yang mengatakan jawaban apa adanya.

\section{Tahapan penelitian}

Proses pengambilan data eksperimen dilakukan di laboratorium, alat yang digunakan adalah 2 buah kamera telephone selular, yang pertama digunakan untuk merekam keseluruhan wajah subjek, dan yang kedua digunakan untuk merekam keseluruhan tubuh subjek. Dalam pelaksanannya eksperimenter memberikan permainan matematika sederhana kepada para subjek secara bergilir, dimana jawaban dari permainan matematika tersebut sebenarnya sudah diketahui oleh eksperimenter meskipun subjek memberikan jawaban yang tidak benar.

Setelahnya dilakukan observasi terhadap hasil rekaman video para subjek untuk menganalisa reaksi nonverbal yang muncul. Hasilnya terdapat lima 
reaksi utama, dimana reaksi tersebut merupakan reaksi-reaksi yang paling sering dimunculkan oleh subjek ketika ditanya tentang informasi hasil hitung yang telah subjek simpan. Lima reaksi tersebut adalah menaikkan alis, cara mata memandang (kearah kiri atas), pola gerak bibir saat berucap (berlebihan), tersenyum (agak tertawa), cara berucap (ada jeda). Rentang skor yang diberikan pada tiap reaksi adalah antara 1 dan 2, 1 untuk tidak adanya reaksi yang muncul, 2 untuk adanya reaksi yang muncul.

\section{Hasil dan Pembahasan}

\section{Alur Kognitif Berbohong}

Penelitian menunjukkan bahwa lima tahapan proses kognitif berbohong yang telah digunakan dalam penelitian ini terbukti sebagai tahapan yang berurutan. Hal ini terlihat dari hasil skor uji reprodisibilitasnya yakni sebesar 0,904. Artinya proses kognitif berbohong dimulai dari adanya informasi mengenai pengalaman yang disimpan, itu artinya analisis kebohongan harus didasarkan pada pengalaman yang dimiliki oleh individu, jika individu ditanyakan tentang suatu informasi yang sebenarnya mereka tidak miliki, maka jawaban yang mereka berikan tidak dapat dikatakan berbohong.

Tabel 1. Sistematika Kognitif Berbohong

\begin{tabular}{|c|c|c|c|c|c|c|}
\hline \multirow[b]{2}{*}{ Subjek } & \multicolumn{5}{|c|}{ TAHAP KOGNITIF BERBOHONG } & \multirow[b]{2}{*}{$\begin{array}{l}\text { Total } \\
\text { Skor }\end{array}$} \\
\hline & Pengalaman & $\begin{array}{l}\text { Informasi } \\
\text { yang } \\
\text { tersimpan }\end{array}$ & Review & Modifikasi & Mengatakan & \\
\hline S1 & 0 & 0 & 0 & 0 & 0 & 0 \\
\hline $\mathrm{S} 2$ & 0 & 0 & 0 & 0 & 0 & 0 \\
\hline S3 & 1 & 0 & 0 & 0 & 0 & 1 \\
\hline S4 & 1 & 0 & 0 & 0 & 0 & 1 \\
\hline S5 & 1 & 1 & 0 & 0 & 0 & 2 \\
\hline S6 & 1 & $0 *$ & 1 & 0 & 0 & 2 \\
\hline S7 & 1 & $0 *$ & 1 & 0 & 0 & 2 \\
\hline S8 & 1 & $0^{*}$ & 1 & 0 & 0 & 2 \\
\hline S9 & 1 & $0^{*}$ & 1 & 0 & 0 & 2 \\
\hline S10 & 1 & $0 *$ & 1 & 0 & 0 & 2 \\
\hline S11 & 1 & $0 *$ & 1 & 0 & 0 & 2 \\
\hline S12 & 1 & 1 & 1 & 0 & 0 & 3 \\
\hline S13 & 1 & 1 & 1 & 0 & 0 & 3 \\
\hline
\end{tabular}




\begin{tabular}{ccccccc} 
S14 & 1 & 1 & 1 & 0 & 0 & 3 \\
S15 & 1 & 1 & 1 & 0 & 0 & 3 \\
S16 & 1 & $0^{*}$ & $0^{*}$ & 1 & 1 & 3 \\
S17 & 1 & $0^{*}$ & $0^{*}$ & 1 & 1 & 3 \\
S18 & $0^{*}$ & 1 & 1 & 1 & 1 & 4 \\
S19 & 1 & $0^{*}$ & 1 & 1 & 1 & 4 \\
S20 & 1 & 1 & 1 & 1 & 1 & 5 \\
S21 & 1 & 1 & 1 & 1 & 1 & 5 \\
S22 & 1 & 1 & 1 & 1 & 1 & 5 \\
S23 & 1 & 1 & 1 & 1 & 1 & 5 \\
S24 & 1 & 1 & 1 & 1 & 1 & 5 \\
S25 & 1 & 1 & 1 & 1 & 1 & 5 \\
TOTAL & 22 & 12 & 18 & 10 & 10 & \\
\hline
\end{tabular}

Kemungkinan Eror $(\mathrm{KE})=\sum$ subjek $\mathrm{x} \sum$ dimensi

Margin Eror $(\mathrm{ME})=1-\frac{\sum \text { eror }}{K E}$

$\mathrm{KE}=25 \times 5=125$

$\mathrm{ME}=1-\frac{12}{125}=1-0,906=0,904$

Batas Margin Eror $=0,900$

Memori berperan penting dalam proses modifikasi informasi yang terjadi dalam proses berbohong (Unless, Act, Rose, If, \& Rose, 2015). Orang yang berbohong haruslah memiliki pengalaman yang tersimpan didalam memorinya, tanpa hal tersebut meski seseorang tetap menjawab ketika ditanyai sebuah informasi yang tidak ia miliki maka hal tersebut tidak dikategorikan sebagai berbohong. Ucapan berbohong bukanlah perilaku yang tanpa melibatkan proses berpikir atau bahkan tanpa disadari, karena pada kenyataannya berbohong justru menggunakan proses berpikir yang aktif (Suchotzki et al., 2015). Proses berpikir aktif dapat dilihat dari bagaimana individu mengakses kembali pengalaman yang tersimpan di memorinya ketika individu ditanya mengenai pengalaman tersebut. Berbeda dengan orang yang lupa, hal ini berkaitan dengan masalah neuropsikologikal yang bisa jadi berkaitan dengan meningkatnya resiko penyakit alzaimer, dan tidak tersedianya informasi di dalam koding memori, atau ketidaktahuan (Sala et al., 2005).

Lupa merupakan kegagalan individu dalam mengakses informasi yang tersimpan di memori (Gu, Li, \& Cai, 2008). Mengakses memori dalam proses kognitif disebut sebagai rehearsal, atau mengingat kembali (Griffith \& Harris, 
2012). Saat individu mengakses kembali informasi biasanya disertai dengan munculnya tanda-tanda perilaku yang ditampilkan melalui ekspresi. Terlebih lagi ketika informasi sudah berhasil ditemukan tetapi individu melalukan metaevaluasi, yakni menilai keuntungan dan kerugian apabila informasi yang sebenarnya disampaikan. Hasil dari evaluasi akan menentukan kejujuran atau modifikasi informasi.

Tahapan kedua, pengalaman tersimpan didalam memori, ketika ada orang lain yang menanyakan tentang pengalaman tersebut individu tersebut memanggil kembali pengalamannya. Tahapan ketiga, review. Jika hasil review menunjukkan adanya bahaya maka individu melakukan modifikasi terhadap pengalamannya tersebut. Maka jawaban yang diberikan berupa hasil modifikasi yang tidak mencerminkan pengalaman yang sebenarnya.

Ketika hasil evaluasi menunjukkan adanya kerugian, individu memodifikasi informasi. Proses evaluasi dijalankan melalui review kognitif, ada peran dari meta kognitif yang memberikan masukan terkait perlu atau tidaknya memodifikasi informasi. Jika hasil review menunjukkan adanya ancaman ketika individu menyampaikan informasi yang sebenarnya maka ia akan memutuskan untuk melakukan modifikasi dan pada akhirnya individu tersebut akan berbohong. Sebaliknya, jika hasil review tidak menunjukkan adanya bahaya, maka individu akan tetap menyampaikan informasi yang sebenarnya. Sangat jelas terlihat bahwa berbohong bukan merupakan kegagalan mengakses informasi di dalam memori, berbohong merupakan aktivitas kognitif yang disadari. Berbohong dipahami sebagai ketidakjujuran individu dalam mengungkapkan informasi yang sebenarnya. Ketidakjujuran terjadi karena individu berusaha menghindari kerugian dan berusaha mendapatkan keuntungan.

Bagan Alur .1. Proses Kognitif Berbohong

\begin{tabular}{|c|c|c|c|c|}
\hline Tahap 1 & Tahap 2 & Tahap 3 & Tahap 4 & Tahap 5 \\
\hline $\begin{array}{l}\text { Memiliki } \\
\text { pengalaman }\end{array}$ & $\begin{array}{c}\text { Mengakses } \\
\text { pengalaman } \\
\text { karena } \\
\text { ditanya }\end{array}$ & \multirow{2}{*}{$\begin{array}{l}\text { Mereview } \\
\text { keadadaan } \\
\text { jika } \\
\text { mengatakan } \\
\text { yang } \\
\text { sebenarnya }\end{array}$} & \multirow[t]{2}{*}{$\begin{array}{c}\text { Melakukan } \\
\text { modifikasi } \\
\text { jika hasil } \\
\text { review } \\
\text { dinilai } \\
\text { berbahaya }\end{array}$} & $\begin{array}{c}\text { Jawaban } \\
\text { yang } \\
\text { diberikan } \\
\text { hasil } \\
\text { modifikasi }\end{array}$ \\
\hline & $\begin{array}{r}\text { Alur I } \\
\text { Saut H Hutaha }\end{array}$ & & & $\begin{array}{l}\text { etika Berbohong } \\
\text { Fachman Putra }\end{array}$ \\
\hline
\end{tabular}


Jumlah Subjek sebanyak 25. Eror terjadi pada : S6-S11 tahap ke2, S16-S17 tahap ke2 dan 3, S18 tahap ke1, subjek 19 tahap ke 2.

Nilai Koefisien reprosidibitas : 0,904

\section{Reaksi Non-verbal Saat Berbohong}

Eksperimen dilakukan dalam penelitian bertujuan untuk melihat reaksi nonverbal yang mucul ketika terjadi proses kognitif berbohong, didapatkan lima reaksi utama yang paling sering muncul. Yakni (1) menaikkan alis, (2) cara mata memandang (kearah kiri atas), (3) pola gerak bibir saat berucap (berlebihan) (4) tersenyum (agak tertawa) (5) cara berucap (ada jeda). Skor 1 diberikan jika reaksi yang dimaksud tidak muncul atau bias, skor 2 diberikan jika reaksi muncul dan sangat kuat. Pada reaksi gerakan menaikkan alis skor keseluruhan pada subjek yang tidak melakukan modifikasi adalah 12, sedangkan pada subjek yang melakukan modifikasi adalah 14. Pada reaksi cara mata memandang (kearah kiri atas) skor keseluruhan subjek yang tidak melakukan modifikasi adalah 11, sedangkan skor keseluruhan subjek yang melakukan modifikasi adalah 12. Pada reaksi pola gerak bibir saat berucap (berlebihan), skor keseluruhan pada subjek yang tidak melakukan modifikasi adalah 11, sedangkan pada subjek yang melakukan modifikasi adalah 16. Pada reaksi tersenyum (agak tertawa), skor keseluruhan pada subjek yang tidak melakukan modifikasi adalah 15, sedangkan pada subjek yang melakukan modifikasi adalah 18. Pada reaksi cara berucap (ada jeda), skor keseluruhan pada subjek yang tidak melakukan modifikasi adalah 12 , sedangkan pada subjek yang melakukan modifikasi adalah 18 .

Tabel 2. Perbandingan Reaksi Non Verbal

\begin{tabular}{lccc}
\hline \multicolumn{1}{c}{ Reaksi } & \multicolumn{2}{c}{ Skor } & Selisih \\
\cline { 2 - 3 } & $\begin{array}{c}\text { Tidak } \\
\text { Modifikasi }\end{array}$ & Modifikasi & \\
\hline Menaikkan alis & 12 & 14 & -2 \\
$\begin{array}{l}\text { Cara mata memandang (kearah } \\
\text { kiri atas) }\end{array}$ & 11 & 12 & -1
\end{tabular}




\begin{tabular}{lccc}
$\begin{array}{l}\text { Pola gerak bibir saat berucap } \\
\text { (berlebihan) }\end{array}$ & 11 & 16 & -5 \\
$\begin{array}{l}\text { Tersenyum (agak tertawa) } \\
\text { Cara berucap (ada jeda) }\end{array} \quad 15$ & 18 & -3 \\
$\quad 12$ & 18 & -5 \\
\multicolumn{1}{c}{ Total } & 61 & 78 & -16 \\
\hline
\end{tabular}

Hasil ini menunjukkan bahwa kelima reaksi tersebut dapat menjadi indikator reaksi verbal dari proses kognitif berbohong. Gerakan mata telah diidentifikasi sebagai salah satu sumber yang paling dapat diandalkan untuk berbohong dalam komunikasi tatap muka (Mann et al., 2012). Orang yang melakukan kebohongan lebih sering menekan kedua bibirnya bersamaan atau menarik bibir (Matsumoto, Hwang, Skinner, \& Frank, 2011) Gambaran hasil eksperimen mengenai non-verbal menunjukkan bahwa salah satu perilaku nonverbal yang muncul saat kebohongan terjadi adalah tersenyum dan tertawa (Hurley \& Frank, 2011). Ekspresi wajah bukan satu-satunya sumber yang dapat dijadikan indikator dalam mengenali kebohongan, sumber lain yang dapat digunakan adalah parabahasa (Mchaney, George, \& George, 2018). Penelitian ini juga mendapatkan adanya reaksi cara berucap, dalam hal ini terciptanya jeda pada subjek ketika diminta untuk mengatakan jawaban. Salah satu elemen parabahasa adalah jeda saat berbicara yang dapat menjadi salah satu indikasi berbohong (Porter \& Ten Brinke, 2010). Terakhir kenaikan alis, alis yang diangkat dan ditarik bersama-sama biasanya menunjukkan rasa takut (Pérez-Rosas, Abouelenien, Mihalcea, \& Burzo, 2015).

\section{Kesimpulan dan Saran}

Proses berbohong muncul melalui aktivitas kognitif yang sistematis, dan ditandai dengan adanya proses berfikir untuk memodifikasi informasi sebenarnya. Prosesnya berlangsung secara berurutan dan tidak mungkin terjadi secara acak. Sehingga ketika seseorang berkata bohong, maka kognitifnya sudah bekerja sebelumnya untuk menciptakan kata-kata yang tidak mencerminkan informasi 
yang sebenarnya. Sebelum menciptakan informasi palsu, kognitif bekerja melakukan review mengenai dampak jika informasi yang sebenarnya disampaikan.

Setiap proses kognitif yang berlangsung memunculkan beberapa reaksi yang sering muncul, khususnya reaksi disekitar wajah, dan terjadinya jeda ucapan (ketika diminta untuk memberikan jawaban). Melalui lima reaksi yang muncul, antara kelompok yang jujur dan yang berbohong menunjukan skor yang berbeda secara signifikan. Dimana nilai kelompok yang berbohong lebih besar dibandingkan dengan kelompok yang jujur. Gerakan alis yang meningkat, cara mata memandang, gerakan bibir yang ditarik, tersenyum (ketawa kecil), dan munculnya jeda dalam memberikan jawaban menjadi reaksi utama yang muncul ketika proses kognitif terjadi. Subjek yang berbohong mempunyai skor reaksi yang lebih besar dari subjek yang jujur.

Masih terdapat beberapa eror kecil pada skor subjek, ketika dilakukan uji reprodisibilitas. Belum ada pembahasan tentang eror tersebut dalam penelitian ini. Apakah disebabkan karena kesalahan subjek dalam memberikan jawaban, atau ada kemungkinan penempatan antara satu tahapan dengan tahapan yang lain (terjadi eror) masih belum tepat secara sempurna. Ada beberapa indikator kebohongan yang masih perlu diuji konsistensi kemunculannya. Kedepanya dalam melihat ekspresi nonverbal disarankan untuk menggunakan penelaahan menggunakan eye tracking untuk melihat pola tatapan mata, analisis terhadap reaksi wajah untuk mengidentifikasi kebohongan terkesan masih bersifat subjektif konfirmatori. Ekspresi dikonfirmasikan berdasarkan kelompok eksperimen yang tidak mengatakan sebenarnya, kemudian analisisnya hanya terbatas pada ekspresi wajah yang terlihat.

\section{Daftar Pustaka}

Abdi, H. (2010). 1 Introduction 2 An example of a perfect Guttman scale. Encyclopedia of Reseacrh Design, 1-5.

Bond, G. D. (2008). Deception detection expertise. Law and Human Behavior, 32(4), 339-351. https://doi.org/10.1007/s10979-007-9110-z 
Buller, D. B., Buendel, K., \& Burgoon, J. K. (2006). Interpersonal Deception Theory, (March). https://doi.org/10.1111/j.1468-2885.1996.tb00127.x

Burgoon, J. K., \& Schuetzler, R. (2014). Patterns of Nonverbal Behavior Associated with Truth and Deception $\square$ : Illustrations from Three Experiments Patterns of Nonverbal Behavior Associated with Truth and Deception $\square$ : Illustrations from Three Experiments, (August). https://doi.org/10.1007/s10919-014-0181-5

Carrión, R. E., Keenan, J. P., \& Sebanz, N. (2010). Brief article A truth that's told with bad intent $\square$ : An ERP study of deception, 114, 105-110. https://doi.org/10.1016/j.cognition.2009.05.014

Debey, E., Houwer, J. De, \& Verschuere, B. (2007). Lying Relies on the Truth. Proteins, 32(May), 118-128. https://doi.org/10.1002/prot

Granhag, A., Porter, S., \& Vrij, A. (2010). Pitfalls and Opportunities in Nonverbal and Verbal Lie Detection. https://doi.org/10.1177/1529100610390861

Griffith, D. A., \& Harris, L. L. (2012). Eye Movements and Other Cues to the False Answers, 39(7), 887-909. https://doi.org/10.1177/0093854812437014

Gu, J., Li, W., \& Cai, X. (2008). P HYSICAL J OURNAL B The effect of the forget-remember mechanism on spreading, 255, 247-255. https://doi.org/10.1140/epjb/e2008-00139-4

Hurley, C. M., \& Frank, M. G. (2011). Executing Facial Control During Deception Situations. Journal of Nonverbal Behavior, 35(2), 119-131. https://doi.org/10.1007/s10919-010-0102-1

Mann, S., Vrij, A., Leal, S., Granhag, P. A., Warmelink, L., \& Forrester, D. (2012). Windows to the Soul? Deliberate Eye Contact as a Cue to Deceit. Journal of Nonverbal Behavior, 36(3), 205-215. https://doi.org/10.1007/s10919-012-0132-y

Matsumoto, D., Hwang, H. S., Skinner, L., \& Frank, M. (2011). Evaluating Truthfulness and Detecting Deception, np. https://doi.org/10.1002/mus.24009

Mchaney, R., George, J. F., \& George, J. F. (2018). Deception Detection $\square$ : An Exploration of Annotated Text-Based Cues Deception Detection $\square$ : An Exploration of Annotated Text-Based Cues, 2018(2). https://doi.org/10.17705/3jmwa.000041

Pak, J., \& Zhou, L. (2013). Social structural behavior of deception in computer- 
mediated communication.

Pérez-Rosas, V., Abouelenien, M., Mihalcea, R., \& Burzo, M. (2015). Deception Detection using Real-life Trial Data, 59-66.

Porter, S., \& Ten Brinke, L. (2010). The truth about lies: What works in detecting high-stakes deception? Legal and Criminological Psychology, 15(1), 5775. https://doi.org/10.1348/135532509X433151

Sala, S. Della, Cowan, N., Perini, M., Ospedaliera, A., Abate, S. A., \& Va, G. (2005). Just lying there, remembering $\square$ : Improving recall of prose in amnesic patients with mild cognitive impairment by minimising interference, 13, 3-8. https://doi.org/10.1080/09658210344000387

Suchotzki, K., Crombez, G., Smulders, F. T. Y., \& Meijer, E. (2015). The cognitive mechanisms underlying deception $\square$ : An event-related potential study, 32(0), 1-36.

Unless, R., Act, P., Rose, W., If, T., \& Rose, W. (2015). Liar, liar, working memory on fire: Investigating the role of working memory in childhood verbal deception.

Verschuere, B., Kleinberg, B., \& Theocharidou, K. (2014). Rt-Based Memory Detection: Item Saliency Effects In The Single-Probe And The MultipleProbe Protocol Article 